neofilolog

Czasopismo Polskiego Towarzystwa Neofilologicznego

ISSN 1429-2173, elSSN 2545-3971, 2021, NR 57/1, 119-133

http://dx.doi.org/10.14746/n.2021.57.1.8

http://poltowneo.org/

Monika Grabowska

Uniwersytet Wrocławski https://orcid.org/0000-0001-7828-0821 monika.grabowska@uwr.edu.pl

Agata Zapłotna

Uniwersytet Wrocławski https://orcid.org/0000-0001-6013-827X agata.zaplotna2@uwr.edu.pl

\title{
Samoświadomość metakognitywna w kształceniu sprawności pisania na studiach neofilologicznych. Na przykładzie italianistyki Uniwersytetu Wrocławskiego
}

\section{The role of metacognitive self-consciousness in teaching writing skills at the neophilological faculty. Example of the Italian Studies at the University of Wroctaw}

The paper presents the results of a survey conducted in the academic year 2018/2019 among students of Italian Studies at the University of Wroclaw on metacognitive self-consciousness concerning Italian writing proficiency. The questions concerned the students' practice of written forms of expression in their private lives; the contribution (actual or anticipated) of writing proficiency in their current and future professional career; and the evaluation of the teaching of writing proficiency within the university curriculum of Italian Studies. The study was qualitative and conducted from an emic perspective, involving students in metacognitive reflection. The results of the study indicate limited metacognitive self-consciousness on the part of the students of Italian Studies, who are not, however, devoid of any criticism of the practical Italian language course curriculum.

Keywords: metacognitive self-consciousness, metacognitive reflexion, writing skills, Italian studies 
Słowa kluczowe: samoświadomość metakognitywna, refleksja metakognitywna, sprawność pisania, italianistyka

\section{Przedmiot badań}

Przedmiotem artykułu jest kształcenie sprawności pisania na studiach neofilologicznych na przykładzie kierunku italianistyka Uniwersytetu Wrocławskiego (UWr).

Tworzenie tekstów pisemnych jest jednym z najistotniejszych komponentów programów neofilologicznych: praktykowanym w każdym semestrze studiów w różnym wymiarze na większości zajęć i podlegającym regularnej ocenie. Pełni także funkcję dystynktywną: neofilolog należy do elitarnej grupy użytkowników języka obcego, która po trzech latach studiów powinna opanować sprawność pisania na poziomie C1 Europejskiego Systemu Opisu Kształcenia Językowego (ESOKJ, 2003). Ponadto na progu trzeciego dziesięciolecia dwudziestego pierwszego wieku obserwujemy rosnący rozdźwięk między gatunkami i formami akademickimi (ang. academic literacy), a tzw. piśmiennością dwudziestego pierwszego wieku (ang. 21st century literacy), któremu pokolenie $Z^{1}$ i kolejne oddają się z trudną do zrozumienia przez ich poprzedników intensywnością. Pojęcie piśmienności dwudziestego pierwszego wieku obejmuje nie tylko produkcję tekstów pisemnych, ale implikuje całą różnorodność form wyrazu oferowaną przez media cyfrowe w przestrzeni wirtualnej, ze szczególnym uwzględnieniem ich charakteru multimodalnego, hipertekstowego i twórczej współpracy (Hulin, Pélissier, 2014). Ten ostatni aspekt podkreślony jest również przez Wilczyńską, Mackiewicza i Krajkę (2019: 462), którzy za istotną cechę "nowych nowych mediów"2 uznają budowanie społeczności i wspólne tworzenie treści, obejmujące również „nowe spojrzenie na ochronę własności intelektualnej [...] w kontekście łączenia i przenoszenia treści z pierwotnych

${ }^{1}$ Przez pokolenie Z rozumiemy pokolenie „ludzi urodzonych mniej więcej w latach 1981-95, które jako pierwsze dorastało w skomputeryzowanym świecie, z mediami społecznościowymi w wymiarze nie tylko zawodowym, ale i towarzyskim. [...]. Internet to ich środowisko naturalne"

(Wardzała, https://www.polityka.pl/tygodnikpolityka/spoleczenstwo/1931474,1,20-I atki-odrzucajaca-konsumpcyjny-styl-zycia-rodzicow.read [DW 02.02.2021]).

2 Wilczyńska, M ackiewicz i Krajka (2019: 461) stosują ten termin w ślad za badaczami, którzy pragną podkreślić innowacyjność rozwiązań oferowanych przez narzędzia web 2.0 (nowe serwisy społecznościowe, now e blogi takie jak YouTube, Digg, Facebook, Twitter), a jednocześnie „pozbyć się tej etykiety [web 2.0], która nie zawsze jest dobrze postrzegana po kryzysie bańki internetowej w latach 2000-2001 (dot-com bubble)". 
Samoświadomość metakognitywna w kształceniu sprawności pisania na...

lokacji do własnych mikroświatów elektronicznych". Uczniowie i studenci wydają się kompetentni w zakresie redakcji tekstów pisemnych przy udziale nowych technologii, ale stworzone przez te technologie gatunki (sms, blog, forum, czat, podcast, portal społecznościowy...) nie zawsze są uznawane za pełnoprawne w stosunku do gatunków obowiązujących w programach akademickich, przede wszystkim ze względu na charakter wspólnotowy tych pierwszych, stojący w sprzeczności z wymogami indywidualnej ewaluacji pracy studenta/ucznia w sytuacji nauczania instytucjonalnego.

W tym kontekście istotne wydaje nam się zdiagnozowanie:

- samoświadomości studentów w zakresie praktyk pisarskich stosowanych przez nich w ramach działań nieformalnych i pozaformalnych podejmowanych czy to w procesie uczenia się pozaakademickiego, czy dla rozrywki, lub też w ramach działalności społecznej;

- ich wyobrażeń dotyczących udziału produkcji pisemnej w przyszłej pracy zawodowej;

- ich oceny realizowanego programu nauczania języka pisanego (w tym przypadku włoskiego) przez pryzmat potencjalnej przystawalności tego programu do potrzeb obecnego i przyszłego świata (ze szczególnym uwzględnieniem rynku pracy).

\section{Metodologia}

Według Prensky'ego (2001a; 2001b) jedyną drogą uniknięcia frustracji związanej z nauczaniem cyfrowych tubylców (ang. digital natives) jest poproszenie ich samych o zapoznanie nauczycieli, cyfrowych imigrantów (ang. digital immigrants) ze stosowanymi przez nich sposobami funkcjonowania w świecie technologii informacyjnych ${ }^{3}$. Zgodnie z tym postulatem w semestrze letnim roku akademickiego 2018/2019 wszyscy studenci wrocławskiej italianistyki wzięli udział w badaniu ankietowym, odpowiadając na szereg pytań dotyczących:

- praktykowania pisemnych form wypowiedzi w życiu prywatnym (w języku ojczystym i w językach obcych);

- udziału (rzeczywistego bądź przewidywanego) sprawności pisania w ich obecnym i przyszłym życiu zawodowym (w języku ojczystym i w językach obcych);

- oceny nauczania sprawności pisania w ramach uniwersyteckiego programu zajęć na kierunku italianistyka UWr (studia licencjackie) ${ }^{4}$.

3 "We need to invent Digital Native methodologies for all subjects, at all levels, using our students to guide us" (Prensky, 2001a: 6).

${ }^{4}$ Ankieta zawarta jest $w$ aneksie do artykułu. 
Zgodnie z myślą Socketta, badacza nieformalnego uczenia się (ang. informal learning) języków obcych, zastosowana w ankiecie metodologia jakościowa, analizująca odpowiedzi na pytania otwarte w perspektywie emicznej (Pike, 1967), angażuje uczącego się w refleksję metakognitywną ${ }^{5}$. M etodologia jakościowa pozwala również uniknąć przypisania poszczególnym ankietowanym najczęstszych wyników grupy oraz, przeciwnie, przypisania grupie wyników określonych osób.

W naszym badaniu podejście emiczne miało pozwolić na ocenę samoświadomości metakognitywnej studentów italianistyki w odniesieniu do badanej sprawności. Dodatkowo badanie zakładało możliwość określenia korzyści dydaktycznych w odniesieniu do procesu nauczania języka włoskiego: diagnozę umiejętności i potrzeb studentów w zakresie sprawności pisania oraz, w miarę możliwości i w dalszej perspektywie, dostosowanie do nich programu zajęć.

\section{Ramy teoretyczne}

Angielski termin metacognition (pl. metakognicja, metapoznanie - słów tych będziemy używać zamiennie ${ }^{6}$ ) został zaproponowany przez Flavella w latach siedemdziesiątych dwudziestego wieku na określenie planowania, monitorowania i ewaluacji własnych procesów poznawczych. W niniejszej pracy przez refleksję metakognitywną będziemy rozumieć za Łompiesiem (2018: 138) „zbiór czynności kognitywnych, kontrolujących i sterujących strategiami ludzkiego myślenia i działania”. Jak zauważa Zdybel (2015: 55), „słynne zawołanie Sokratesa: «wiem, że nic nie wiem» jest doskonałą ilustracją metapoznawczego wglądu we własny umysł".

M etapoznanie z reguły ukazywane jest jako „jeden z podstawowych czynników warunkujących sukces w uczeniu się oraz za jeden z najlepszych predyktorów osiągnięć szkolnych i akademickich" (Czerniawska, 2005: 56). Zdaniem Wenden (1998: 519) na świadomość metakognitywną składają się takie kompetencje jak: zdolność do określania roli czynników kognitywnych i afektywnych we własnych procesach akwizycyjnych, zrozumienie celu danego zadania w odniesieniu do własnych mechanizmów poznawczych oraz

5 „„[...] notre utilisation du terme émique ira au-delà de la simple centration sur l'apprenant évoquée par Larsen-Freeman et Cameron (2008) et engagera les apprenants directement dans le processus de collecte de données sur leur propre apprentissage" (Sockett, 2012: §13).

${ }^{6} \mathrm{~W}$ polskiej literaturze przedmiotu możemy spotkać również terminy zbliżone, o niejasnej relacji w stosunku do metapoznania, takie jak: metauczenie się, świadomość strategiczna, refleksyjność (szerzej na ten temat: Zdybel 2015). 
Samoświadomość metakognitywna w kształceniu sprawności pisania na...

wiedza na temat stosowanych w procesie uczenia się strategii i ich przydatności w procesach akwizycyjnych.

Eksploracja dydaktyczna metapoznania może zostać zakłócona wskutek werbalizacji (Zając, 2009: 178-179). Dzieje się tak ze względu na fakt, że, po pierwsze, stany świadomości i samoświadomość nie są tożsame, a po drugie, ta ostatnia jest obarczona błędami wynikającymi z czterech różnych przyczyn: samooszukiwania, błędnych interpretacji, myślenia życzeniowego i nieuwagi. Przeprowadzając ankietę, byłyśmy świadome niemożliwości wyeliminowania tych procesów, stąd też wnioski traktować będziemy w kategoriach wskazówek i tendencji, a nie analizy danych wynikających z obiektywnej percepcji.

M etakognicja wpływa na autonomizację procesu uczenia się, sprzyjając postawie świadomej, refleksyjnej i proaktywnej. Niemniej jednak tych dwóch pojęć nie należy utożsamiać: student może być w stanie dokonać pogłębionej analizy metapoznawczej bez poprawy rezultatów procesu uczenia się, może też być w stanie uczyć się skutecznie, nie będąc świadomym stosowanych strategii (Garcia, O'Connor, Cappellini, 2007: 72). Tym samym istotne wydaje się rozróżnienie między refleksją metakognitywną a kompetencją metakognitywną, która odnosi się do skutecznego posługiwania się strategiami metakognitywnymi obejmującymi planowanie, monitoring i ewaluację procesu uczenia się ${ }^{7}$ (por. klasyczne klasyfikacje strategii uczenia się: Oxford, 1990; O’Malley, Chamot, 1990).

Wpływ samoświadomości metakognitywnej na skuteczne uczenie się języków obcych stał się przedmiotem szeregu opracowań w różnych kontekstach (np. Bucko, 2017; Łompieś, 2018; Zając, 2009) wykazując istotną korelację z osiąganymi wynikami:

Wgląd w przebieg procesu poznania jest niemal automatyczny i spontaniczny u osób inteligentnych, przybiera on wręcz postać "programu poznawczego" opartego na selektywnym kodowaniu, kombinowaniu oraz porównywaniu danych. Program ten jest nieobecny, lub obecny w niewielkim stopniu, u uczniów mało zdolnych. Dla glottodydaktyki ów program poznawczy, prowadzący do efektywnego uczenia się, ma kapitalne znaczenie. Znajomość jego struktur, pełnionych funkcji i ich związku z procesami poznawczymi, a także sposobów wywoływania i trenowania - powinna w sposób bardzo intensywny zaistnieć zarówno w działaniach dydaktycznych jak i jako refleksja na etapie kształcenia przyszłych nauczycieli języków obcych. (Zając, 2009: 175)

Ostatni postulat zachęcił nas do podjęcia próby wglądu w samoświadomość metapoznawczą studentów Instytutu Filologii Romańskiej (IFR) UWr, zasadniczo

\footnotetext{
${ }^{7}$ W skład umiejętności uczenia się (savoir-apprendre, ESOKJ 2003: 98) wchodzi również wrażliwość językowa i komunikacyjna, ogólna sprawność fonetyczna i sprawności heurystyczne.
} 
należących do kategorii zdolnych uczniów ${ }^{8}$, w odniesieniu do sprawności pisania i w korelacji z elementami uczenia się pozaakademickiego odbywającego się obecnie (także przed pandemią covid-19) w dużej mierze w środowisku nowych technologii.

\section{Profil uczestników badania}

W ankiecie wzięło udział 29 (100\%) studentów w wieku od 19 do 25 lat, w tym 24 kobiety (83\%) i 5 mężczyzn (17\%). 13 osób (45\%) zadeklarowało, że italianistyka jest ich drugim kierunkiem, przy czym ponad jedną piątą badanych stanowili studenci lub absolwenci innych filologii. Większość ankietowanych miała za sobą pierwsze doświadczenia zawodowe (67\%), zaś co trzecia osoba pracowała już z językiem włoskim w sektorze edukacji (14\%), tłumaczeniach (10\%) lub obsłudze klienta (7\%).

Z analizy nawyków pisarskich w życiu prywatnym wyłania się obraz studenta wrocławskiej italianistyki jako aktywnego twórcy komunikatów medial-

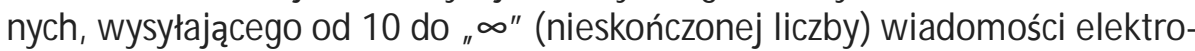
nicznych dziennie. Wszyscy uczestnicy badania utrzymują regularną korespondencję mailową (ze średnią 5 wiadomości tygodniowo), ponadto jedna trzecia wszystkich ankietowanych systematycznie wyraża opinię za pośrednictwem wpisów w mediach społecznościowych. Choć nieustanna potrzeba łączności ze światem manifestuje się głównie w komunikacji cyfrowej, nieobce są studentom tradycyjne formy epistolarne takie jak list lub kartka pocztowa - ponad połowa badanych wysyła je średnio cztery razy w roku. Pisarska aktywność przedstawiciela pokolenia Z nie ogranicza go do roli producenta setek prywatnych wiadomości - co druga osoba deklaruje częste uprawianie form artystycznych takich jak tłumaczenia (59\%), wiersze (18\%), scenariusze sztuk teatralnych (12\%) oraz reportaże i opowiadania (11\%). Cyfrowi tubylcy unikają jednak propagowania swej twórczości za pośrednictwem blogów, które według ankiet stanowią najrzadziej uprawianą formę (o doświadczeniach w blogosferze informuje zaledwie co piąty ankietowany). Wśród piśmiennictwa użytkowego studenci wymieniają natomiast notatki (59\%), pisma urzędowe związane z uczelnią lub pracą (21\%) oraz prowadzenie pamiętnika (14\%).

Obok prywatnej twórczości na użytek własny, pisanie należy do służbowych obowiązków ponad połowy aktywnych zawodowo studentów (59\%). Wśród najczęstszych aktywności pisarskich wymieniają prowadzenie komunikacji mailowej z klientem (41\%), wykonywanie tłumaczeń (34\%), sporządzanie

\footnotetext{
${ }^{8}$ Świadczyć 0 tym może liczba kandydatów $(10,8)$ na jedno miejsce na kierunku italianistyka w procesie rekrutacji na rok akademicki 2020/2021 na UWr.
} 
Samoświadomość metakognitywna w kształceniu sprawności pisania na...

dokumentacji korporacyjnej takiej jak raporty i konspekty (24\%) oraz pisanie artykułów (21\%). W dalszej karierze zawodowej przewidują zajmowanie się działalnością tłumaczeniową (66\%), pisanie raportów i maili (41\%), artykułów (31\%) oraz listów formalnych (21\%). Planują przy tym pisać po włosku, polsku oraz w innych znanych im językach (m. in. angielskim, hiszpańskim, rosyjskim i szwedzkim).

\section{Analiza badania ankietowego}

\subsection{Ocena programu przedmiotu Praktyczna Nauka Języka Włoskiego (PNJW) - Pisanie w kontekście potrzeb oraz kompetencji językowych studentów}

Scharakteryzowany powyżej profil pisarskich praktyk adeptów wrocławskiej italianistyki jedynie częściowo pokrywa się z ich oczekiwaniami wobec programu zajęć, przy czym preferencje studentów różnią się w zależności od roku studiów. Prawie wszyscy studenci I roku (93\%) uważają, że liczba godzin przeznaczonych na rozwój sprawności pisania jest odpowiednia9 ${ }^{9}$. W tóruje im niemal połowa starszych kolegów (48\%), którzy podkreślają jednak, że przewidziane treści programowe nie są spójne z pozostałymi aspektami praktycznej nauki języka włoskiego, co utrudnia osiągnięcie zakładanych efektów kształcenia. Pozostali studenci II i III roku (62\%) uważają natomiast, że italianistyka na UWr oferuje zbyt mało godzin przewidzianych na zajęcia PNJW-Pisanie; według nich optymalnym rozwiązaniem byłoby przeznaczenie 2-3 jednostek zajęciowych w tygodniu wyłącznie na rozwój tej sprawności.

Różnice pomiędzy preferencjami studentów różnych lat są dostrzegalne także w ich oczekiwaniach wobec kompetencji rozwijanych na zajęciach. Dla studentów I roku kluczowa jest poprawność leksykalna, gramatyczna oraz interpunkcyjna (64\%). W dalszej kolejności oczekują rozwijania kreatywności (18\%) oraz umiejętności sprawnego konstruowania różnych form pisarskich (18\%). Starszych italianistów charakteryzują bardziej rozbudowane oczekiwania względem zajęć mających, ich zdaniem, stanowić okazję do doskonalenia warsztatu akademickiego i formalnego. Za najważniejsze uważają zatem dbanie o przejrzystość tekstu oraz logiczne formułowanie argumentów (40\%), doskonalenie poprawności językowej rozumianej także jako stosowność socjolingwistyczna (33\%) oraz naukę tworzenia bibliografii i pisania tekstów naukowych (20\%).

Podobna różnica występuje również w preferencjach dotyczących pożądanych form nauczanych na zajęciach. Najmłodsi uczestnicy badania za najbardziej przydatne uważają pisma formalne (50\%) oraz tłumaczenia (43\%), natomiast

\footnotetext{
${ }^{9}$ W programie italianistycznych studiów w IFR na PNJW-Pisanie przewidziane są dwie godziny tygodniowo.
} 
niemal połowa studentów starszych lat wolałaby skoncentrować się na tekstach akademickich takich jak dysertacje lub artykuły naukowe (43\%) przy mniejszym zainteresowaniu komunikacją urzędową (29\%) oraz przekładami (14\%). Większość studentów I roku nie wskazuje żadnych nieprzydatnych dydaktycznie form (86\%), podczas gdy ich starsi koledzy negatywnie oceniają wprowadzanie do programu zajęć bajki (33\%), pamiętnika (20\%) oraz bloga (13\%).

Ponad połowa italianistów z II i III roku podkreśla brak korelacji programu zajęć z wymogami ich przyszłego zatrudnienia, krytykując poświęcanie zbyt dużej ilości czasu na ćwiczenie mało przydatnych ich zdaniem form, przeteoretyzowanie praktycznych z założenia zajęć (cytując komentarze, na zajęciach powinno się „więcej pisać, mniej mówić o pisaniu”) oraz brak zintegrowania poszczególnych aspektów praktycznej nauki języka włoskiego. W wymienionych czynnikach badani upatrują źródeł swojej niewystarczającej kompetencji pragmalingwistycznej, określanej przez nich jako „nieumiejętność dostosowania wypowiedzi do sytuacji językowej i odbiorcy komunikatu". We własnej ocenie studenci nie osiągnęli zadowalającej znajomości diafazycznych, diastratycznych i diamezycznych wariantów włoskiego, co może w przyszłości negatywnie wpłynąć na ich życie zawodowe.

Większość studentów w jednoznacznie niekorzystny sposób ocenia własne kompetencje językowe, jako przyczynę tego stanu podając niewłaściwie skonstruowany program studiów. Ponad połowa badanych (55\%) przyznaje się do problemów z gramatyką oraz doborem odpowiedniego słownictwa (52\%), zaś jedna piąta deklaruje brak satysfakcjonującej znajomości konkretnych zw rotów stosowanych w poszczególnych, przeważnie oficjalnych, formach pisarskich - studenci zgłaszają chęć otrzymywania gotowych list ze zwrotami i strukturami używanymi w różnych rodzajach tekstów. Co czwarty italianista zauważa także, że nieznajomość kontekstu kulturow ego uniemożliwia mu uzyskanie poprawności stylistycznej. Większość ankietowanych skarży się również na brak zintegrowania poszczególnych przedmiotów modułu PNJW, objawiający się złą organizacją zajęć („na zajęciach z pisania robi się trochę wszystkiego i niczego"), przez którą ich program „nie jest do końca realizowany”, a cały kierunek jest „bardzo mocno oparty na codziennej komunikacji, tak jak zwykły kurs w szkole".

\subsection{Samoświadomość w uczeniu się}

Studenci italianistyki wykazują braki w zakresie wiedzy na temat mechanizmów akwizycyjnych, a także roli, jaką pełni przejęcie odpowiedzialności za własny proces uczenia się. Choć większość badanych deklaruje niesatysfakcjonujący poziom własnych kompetencji językowych, ich pozaakademicki nakład pracy jest niewielki lub zerowy. średni czas poświęcany przez studentów na 
rozwój sprawności pisania poza zajęciami w IFR to zaledwie dwie godziny tygodniowo (wliczając w to przygotowanie prac domowych). Za dydaktycznie nieprzydatną uznawana jest komunikacja nieformalna (elektroniczna i tradycyjna) (45\% ankietowanych) oraz tworzenie notatek (38\%), a zatem formy najczęściej uprawiane przez młodych italianistów. Ankieta nie wykazuje także większego zainteresowania respondentów tłumaczeniami, które - choć wspominane przez uczestników badania w kontekście prawdopodobnej dalszej kariery - nie są uznane za warte formalnego nauczania (zainteresowanie praktykami tłumaczeniowymi deklaruje zaledwie 14\% badanych). Przyczyną tego stanu może być zbyt wąskie pojmowanie sprawności pisania: refleksje studentów ograniczają się bowiem do przedmiotów związanych z praktyczną nauką pisanego języka włoskiego i nie dotyczą produkcji pisemnej uprawianej podczas innych zajęć przewidzianych w programie studiów.

Podejmowane przez badanych dodatkowe działania własne są chaotyczne. Za najważniejszy czynnik usprawniający sprawność pisania uważają czytanie w języku docelowym (55\% odpowiedzi), wybierają przy tym jednak teksty niepokrywające się z sygnalizo wanymi w ankiecie potrzebami - przykładowo, jak deklaruje jedna z uczestniczek badania, w celu doskonalenia kompetencji w zakresie tworzenia pism formalnych czyta krótkie formy artystyczne. Jedynie nieliczni (17\%) decydują się na uprawianie dodatkowej produkcji pisemnej, takiej jak prowadzenie pamiętnika w języku kierunkowym, sporządzanie notatek oraz utrzymywanie internetowej komunikacji ze znajomymi native speakerami. Znamienna jest także krytyka dominującej na zajęciach komunikatywnej metody nauczania określanej przez studentów jako rozwiązanie "niegodne filologii" i odpowiednie dla kursu językowego (badani nie precyzują przy tym jak powinno wyglądać nauczanie "godne" filologii).

Wspomniany wyżej niewielki nakład pracy własnej oraz wynikające z ankiety krytyczne podejście studentów do programu zajęć wskazują na słabo rozwiniętą świadomość metapoznawczą uczestników badania, przejawiającą się w ograniczonej zdolności do autorefleksji w zakresie procesów akwizycyjnych i do samodzielnego doskonalenia (Jaworska, 2020: 198). Studenci nie przejmują odpowiedzialności za proces uczenia się, co wynika z niedostrzegania korelacji pomiędzy jakością ich produkcji a własnym nakładem pracy, a także z braku umiejętności wyobrażenia wymogów rynku pracy. Słabo rozwinięta zdolność do zrozumienia celu zadania językowego w odniesieniu do własnych potrzeb powoduje, że studenci niechętnie podejmują pracę z formami regularnie uprawianymi w życiu codziennym, nie dostrzegając korzyści płynących z takich działań. Ograniczona świadomość przydatności podejmowanych działań powoduje, że decydują się na mało efektywne akwizycyjnie działania oraz postulują odchodzenie od rozwijania samodzielności na rzecz 
oczekiwania zestawu gotowych zwrotów, charakterystycznych dla poszczególnych form pisemnych, które zostaną przekazane przez nauczyciela (świadczyć to może o przywiązaniu do podejścia transmisyjnego w nauczaniu). Warto jednak podkreślić, że studenci trzeciego roku italianistyki charakteryzują się większą zdolnością do refleksji na temat własnych procesów akwizycyjnych niż ich młodsi koledzy, co świadczy o tym, że codzienny kontakt z neofilologicznym środowiskiem rozwija ich świadomość metapoznawczą.

Obszarem, który najbardziej stymuluje autorefleksję na temat procesów poznawczych, jest wybór pomiędzy produkcją komputerową a odręczną. Chociaż ponad połowa badanych przyznaje, że pisanie ręczne sprzyja szybszej akwizycji nowych struktur, większość (76\%) preferuje pisanie na komputerze. Studenci potrafią przy tym scharakteryzować przydatność podejmowanych działań: wśród zalet produkcji elektronicznej wymieniają możliwość sprawnej korekty błędów oraz dostosowanie się do wymogów rynku pracy opartego na komunikacji cyfrowej. Jednocześnie rezultaty ankiety odzwierciedlają powściągliwość w korzystaniu z rozwiązań wirtualnych - pomimo częstego odwoływania się do źródeł internetowych, uczestnicy badania są nieświadomi istnienia zasobów, takich jak ogólnodostępne korpusy językowe, słowosieci, usługi Clarin ${ }^{10}$ lub komputerowe narzędzia tłumacza. Zamiast komputerowych rozwiązań wspierających pracę filologa, największym zaufaniem darzą tradycyjne źródła, takie jak słowniki oraz podręczniki pisania akademickiego.

\section{Wnioski}

W kontekście pierwszego z postawionych we wstępie celów, czyli oceny samoświadomości metakognitywnej uczestników badania, należy stwierdzić, że ankietowani nie wykazują zaawansowanej samoświadomości w zakresie procesów akwizycyjnych oraz gotowości do uczenia się w autonomii lub w warunkach nieformalnych. Przyczyną tego stanu może być brak wstępnego kursu dotyczącego akwizycji i nauki języków obcych, obowiązkowego w programie filologii francuskiej, fakultatywnego w programie filologii hiszpańskiej IFR UWr zależność tę warto by zgłębić. Należy przy tym podkreślić, że nawet wysoki poziom zdolności metapoznawczych „sam w sobie nie stanowi jeszcze gwarancji wysokich osiągnięć w uczeniu się. [...] M etapoznanie powinno być rozpatrywane w kategoriach pewnej potencjalności, która może, choć nie musi zostać uruchomiona w konkretnej sytuacji uczenia się" (Zdybel, 2015: 56-57).

Ograniczona samodzielność studentów w zakresie znajomości mechanizmów akwizycyjnych objawia się niewielkim lub zerowym nakładem pracy

${ }^{10} \mathrm{https}: / /$ clarin-pl.eu. 
Samoświadomość metakognitywna w kształceniu sprawności pisania na...

własnej poza kontekstem formalnym oraz niezdolnością dostrzeżenia celu konkretnych działań dydaktycznych. Niezbędne jest zatem uświadomienie im potrzeby przejęcia odpowiedzialności za własny proces uczenia się; w tym celu warto zachęcać ich do zanurzania się w języku także poza salą zajęciową. Cenną praktykę stanowiłoby, na przykład, uzupełnienie programu zajęć o momenty sprawozdawczo-dyskusyjne, w czasie których podzieliliby się swoimi praktykami nieformalnego uczenia się (Sockett 2012, §51). Uczenie się nieobjęte formami instytucjonalnymi ma bowiem to do siebie, że jest najczęściej nieuświadomione - dopiero po rozmowie zinną osobą (zwłaszcza wykładowcą) uczący się może dojść do wniosku, że wcześniejsze doświadczenia (także ludyczne) mają wartość dodaną: edukacyjną.

W odniesieniu do drugiego z postawionych we wstępie celów, czyli do określenia umiejętności i potrzeb studentów w ramach zajęć Praktycznej Nauki Języka Włoskiego, warto wzbogacić program zajęć praktycznej nauki języka o elementy włoskich wariantów diafazycznych, diastratycznych i diamezycznych; o ile bowiem uwrażliwianie studentów na praktyczne aspekty diatopii jest nieuniknione (szczególnie w formie elementów dialektalnych wprowadzanych w kontekście nowego słownictwa), analizę pozostałych wariantów językowych uniemożliwiają często ograniczenia czasowe. Aspekty te są zaś o tyle ważne, że warunkują nie tylko dobór leksyki (np. odpowiednich spójników tekstowych), lecz wpływają także na wybór konstrukcji gramatycznych (np. kwestia wymienności trybów congiuntivo/indicativo we współczesnym języku włoskim $)^{11}$. Wprowadzanie ich elementów zdaje się więc szczególnie istotne dla rozwoju kompetencji pisania.

Dostrzegalna w ankietach chęć koncentrowania się na pismach urzędowych, a zatem na gatunku najrzadziej uprawianym przez studentów, jest znamienna w kontekście rozwoju kompetencji socjolingwistycznych niezbędnych w korespondencji z instytucjami publicznymi. Wobec utrudnień wynikających z ograniczeń czasowych, poza oczywistym zachęcaniem studentów do poszerzania sprawności we własnym zakresie, warto zatem - szczególnie w odniesieniu do diafazji - położyć większy nacisk na elementy grzeczności językowej. Lepsza kompetencja w tym zakresie pozwoliłaby przyszłym italianistom zmierzyć się z tekstami o wyższym stopniu sformalizowania, a w dalszej perspektywie stworzyłaby bazę do planowanej przez większość respondentów działalności tłumaczeniowej.

${ }^{11}$ We włoskich zdaniach złożonych wybór modalny determinowany jest między innymi stopniem formalności komunikatu oraz rodzajem produkcji: tryb łączący dominuje w języku pisanym i oficjalnym, natomiast w tekstach ustnych i nieformalnych w tych samych kontekstach preferowany jest tryb oznajmujący (Blücher, 2018: 21). 
Wreszcie, jako że pisanie jest makrosprawnością, która integruje inne komponenty kompetencji komunikacyjnej, warto byłoby wprowadzić do programu zalecane przez Komorowską ćwiczenia (2002: 209) oparte na sekwencji: odwzorowywanie tekstu - ćwiczenia wspierające - samodzielne próby pisania, które - poza oczywistymi korzyściami natury pragmatycznej - pomogłyby studentom dostrzec związek pomiędzy poszczególnymi sprawnościami językowymi oraz częściami składowymi modułu PNJW.

Ostatnim istotnym wnioskiem jest refleksja na temat roli nauczyciela pracującego z pokoleniem Z, który w odniesieniu do źródeł internetowych i zasobów elektronicznych powinien pokusić się także o pełnienie funkcji przewodnika cyfrowego. Warto bowiem pochylić się nad kompetencją cyfrową studentów i rozszerzyć ją o nieznane im dotąd narzędzia wirtualne przydatne w pracy filologa. Należy zatem upewnić się, że przyszli neofilolodzy wiedzą, w jaki sposób wzbogacić swój warsztat zarówno w zakresie humanistyki cyfrowej, jak i narzędzi używanych w pracy tłumacza.

Na zakończenie warto mieć nadzieję, że samo przeprowadzenie ankiety dotyczącej świadomości i samoświadomości studentów pełni funkcję stymulującą procesy refleksji metakognitywnej - przynajmniej wśród zdolnych uczniów, a takimi są z pewnością studenci wrocławskiej italianistyki.

\section{BIBLIOGRAFIA}

Blücher K. (2018), Congiuntivo nell'italiano scritto contemporaneo. Roma: Carocci. Bucko D. (2017), Badanie i rozwijanie świadomości metakognitywnej przyszłych nauczycieli języka polskiego jako obcego. „Języki Obce w Szkole”, nr 1, s. 83-87. Czerniawska E. (2005), O złożonych zwiq̨zkach między zdolnościami i metapoznaniem, (w:) Limont W., Cieślikowska J. (red.), Wybrane zagadnienia edukacji uczniów zdolnych, t. 1. Kraków: Impuls, s. 53-73.

Flavell J. H. (1979), M etacognition and Cognitive M onitoring: A New Area of Cognitive Developmental Inquiry. „American Psychologist”, nr 34 (10), s. 906-911.

Garcia N. de M. D., O'Connor K. M., Cappellini M. (2017), A Typology of M etacognition: Examining Autonomy in a Collective Blog Compiled in a Teletandem Environment, (w:) Capellini M., Lewis T., Rivens M ompean A. (red.), Learner Autonomy and Web 2.0. Sheffield UK/Bristol CT: Equinox Publishing Ltd., s. 67-90.

ESOKJ: Europejski system opisu kształcenia językowego (2003). Warszawa: CODN. Hulin T., Pélissier Ch. (2014), Appropriation de l'écriture numérique: évaluation et parcours pédagogique, (w:) Nouailler M . (red.), L'enseignement de l'expression - communication dans les IUT - Fondements théoriques, représentations, réalités. Paris: L'Harmattan. Online : https://halshs.archives-ouvertes.fr/halshs-01153782 [DW 12.11.2020]. 
Samoświadomość metakognitywna w kształceniu sprawności pisania na...

Jaworska M . (2020), Umiejętność uczenia się jako jedna z kompetencji kluczowych - perspektywa nauczycieli języków obcych. „Socjolingwistyka”, nr 34, s. 197-213.

Łompieś J. (2018), Refleksja metapoznawcza w procesie kształtowania sprawności pisania na poziomie akademickim. „Półrocznik Językoznawczy Tertium. Tertium Linguistic Journal", nr 3, s. 138-161.

O'M alley J. M., Chamot A. U. (1990), Learning Strategies in Second Language Acquisition. Cambridge, UK: Cambridge University Press.

Oxford R. (1990), Language Learning Strategies: What Every Teacher Should Know. Boston: Heinle \& Heinle.

Pike K. (1967), Language in Relation to a Unified Theory of Structure of Human Behavior. La Haye: M outon.

Prensky M. (2001a), Digital Natives, Digital Immigrants. „On the Horizon”, vol. 9, nr 5. Online: http://www.marcprensky.com/writing/Prensky\%20\%20Digital\%2 ONatives,\%20Digital\%20lmmigrants\%20-\%20Part1.pdf [DW 04.03.2021]. Prensky M . (2001b), Digital Natives, Digital Immigrants. Part II. Do They Really Think Differently? „On the Horizon” vol. 9, nr 6. Online: https:// www. marcprensky.com/writing/Prensky\%20\%20Digital\%20Natives,\%20Digi tal\%20Immigrants\%20-\%20Part2.pdf [DW 27.02.2021].

Sockett G. (2012), Le web social. La complexité au service de l'apprentissage informel de l'anglais. „Alsic. Apprentissage des Langues et Systèmes d'Information et de Communication", nr 15 (2). Online : http://journals. openedition.org/alsic/2505 [DW 10.12.2020].

Wenden A. L. (1998), M etacognitive knowledge and language learning. „Applied Linguistics", nr 19 (4), s. 515-537.

Wilczyńska W., M ackiewicz M., Krajka J. (2019), Komunikacja interkulturowa. Warszawa: PWN.

Zając J. (2009), Znaczenie metapoznania w rozwijaniu kompetencji uczenia się języka obcego. „Scripta Neophilologica Posnaniensia”, tom X, s. 175-184. Zdybel D. (2015), Metapoznanie - ukryty wymiar kompetencji uczenia się, (w:) Uszyńska-Jarmoc)., Bilewicz M. (red.), Kompetencje kluczowe dzieci i młodzieży. Teoria i badania. Warszawa: Wydawnictwo Naukowe żak, s. 54-70.

Received: 7.04.2021

Revised: 13.09 .2021 


\section{ANEKS \\ KWESTIONARIUSZ DLA STUDENTÓW}

\section{Pisanie w życiu prywatnym}

1.1. Które z poniższych form pisemnych praktykuje Pani/Pan w życiu prywatnym? Proszę podać przybliżoną liczbę tworzonych tekstów, wybierając dogodny okres ewaluacji, jeśli podane są dwa $a^{12}$ :

- $\quad$ smsy lub wiadomości z użyciem innych komunikatorów (messanger, whatsapp itp.):.... dziennie

- e-maile: ...dziennie / ...tygodniowo

- listy nieformalne (do rodziny i znajomych): ... miesięcznie / ... rocznie

- $\quad$ wpisy w mediach społecznościowych: ... dziennie / ...tygodniowo

- wpisy na własnym blogu: ... tygodniowo / ... miesięcznie

- komentarze do blogów: ...tygodniowo / ... miesięcznie

- $\quad$ wpisy w pamiętniku lub dzienniku: ... tygodniowo/ ... miesięcznie

- kartki pocztowe (pozdrowienia z wyjazdów, życzenia): ... miesięcznie / ... rocznie

- notatki: ... dziennie lub ...tygodniowo

- pisma urzędowe: jakie? ile rocznie?

- formularze i kwestionariusze: jakie? ile rocznie?

- formy wyrazu artystycznego (wiersze, opowiadania, reportaże, skecze, wywiady, tłumaczenia itp.): jakie? jak często?

- inne: jakie? jak często?

1.2. Których z poniższych form nie praktykuje Pani/Pan w ogóle?

- Smsy lub wiadomości z użyciem innych komunikatorów

- e-maile

- listy nieformalne

- wpisy w mediach społecznościowych

- wpisy we własnym blogu

- komentarze do blogów

- $\quad$ wpisy w pamiętniku lub dzienniku

- kartki pocztowe

- notatki

- pisma urzędowe

- formularze i kwestionariusze

- formy wyrazu artystycznego (wiersze, opowiadania, reportaże, skecze, wywiady, tłumaczenia itp.)

- innych: jakich?

\footnotetext{
${ }^{12} \mathrm{~Np}$. jeśli ktoś pisze niewiele listów, można oszacować, że jest ich 4-5 w ciągu roku, zamiast podawać wartość 0,5 miesięcznie.
} 
Samoświadomość metakognitywna w kształceniu sprawności pisania na...

1.3. Które z tych form Pani/Pana zdaniem wymagają nauczania (w szkole lub na studiach)? 1.4. Które z tych form Pani/Pana zdaniem nie wymagają nauczania (w szkole lub na studiach)?

\section{Pisanie w życiu zawodowym}

2.1. Czy pracuje Pani/Pan obecnie albo pracowała/pracował wcześniej? Jeśli tak, jaka to jest/była praca? (jeśli nie, proszę przejść od razu do pytania 2.3).

2.2. Czy Pani/Pana praca wiąże się/wiązała się z pisaniem? Jeśli tak, jakiego rodzaju są/były to zadania (tłumaczenia, artykuły, zamówienia, oferty, raporty, maile, CV, listy, opracowania, konspekty, prezentacje, kwestionariusze, ...)? W jakim języku?

2.3. Jakie Pani/Pana zdaniem formy pisemne będzie Pani/Pan praktykować w przyszłym życiu zawodowym (tłumaczenia, artykuły, zamówienia, oferty, raporty, maile, CV, listy, opracowania, konspekty, prezentacje, kwestionariusze, ...)? W jakim języku?

\section{Pisanie w ramach studiów w IFR}

3.1. Ile czasu poświęca Pani/Pan średnio w tygodniu na przygotowywanie pisemnych prac domowych na potrzeby wszystkich zajęć na studiach w IFR?

3.2. Z jakich pomocy naukowych Pani/Pan korzysta?

3.3. Czy liczba godzin zajęć z pisania w ramach praktycznej nauki języka włoskiego (PNJW) jest Pana/Pani zdaniem odpowiednia? Jeśli nie, jaka liczba byłaby Pana/Pani zdaniem satysfakcjonująca?

3.4. Na jakie umiejętności w zakresie pisania na zajęciach PNJW powinien być Pani/Pana zdaniem położony największy nacisk?

3.5. Jakie formy pisemne powinny być intensywnie(j) ćwiczone na studiach w IFR?

3.6. Czy jakieś zadania pisemne wydają się Pani/Panu niepotrzebne w ramach studiów w IFR? Które i dlaczego?

3.7. Jakie są Pani/Pana największe trudności związane z pisaniem w języku włoskim?

3.8. Czy podejmuje Pani/Pan działania poza studiami w IFR mające na celu poprawienie jakości wypowiedzi pisemnych? Jeśli tak, jakie?

3.9. Czy woli Pani/Pan pisać na komputerze czy ręcznie? Jakie są Pani/Pana zdaniem wady i zalety pisania na komputerze? 